\title{
The Role of Celebrity Radio DJs in Contemporary Radio Industry: A Case Study of Prambors Network
}

\author{
KARTIKA SINGARIMBUN \\ SITI KARLINAH \\ DADANG RAHMAT HIDAYAT \\ Universitas Padjadjaran, Indonesia \\ YULIANDRE DARWIS \\ Universitas Andalas, Indonesia
}

\begin{abstract}
In music radio broadcasts, radio DJs play an important role in the success of broadcast programs. The words and expressions used are very important in building relationships with the listener. As a form of business development, Prambors Radio forms a network that broadcasts homogeneous content simultaneously. For efficiency reason, the company uses national television celebrities as radio DJs for the listeners' needs. This study uses the commercial radio station Prambors Radio Network broadcast in nine cities in Indonesia as an exemplar for understanding the commodity process of radio workers. Using Vincent Mosco's key theories, the commodification of labor, to explain how services and ideas transform into commodities or trade objects, this research argues that Prambors Network uses national celebrity radio DJs not only to broaden the broadcast reached, but also to attract advertisers as well. Celebrity radio DJs, in particular, are leased by the company to the fans and are expected to increase audience number (share) for the benefit of client products. Through qualitative interviews with radio owners, workers, and observations, this research shows that Prambors Network has created a new strategy to build proximity with listeners by utilizing celebrity radio DJs for AC Nielsen radio rating and number of listeners. Their fame is used in all radio promotional materials, both on prime time morning show and promotion of the radio brand itself. The results of the exploitation of national celebrities as radio DJs are marginalization of local human resources and the broadcasting of Jakarta-centric information.
\end{abstract}

Keywords: Commodification, exploitation, labor, Indonesian radio network, celebrity radio DJ.

\section{INTRODUCTION}

Employing national celebrities on radio broadcasting is one of the most creative strategies in developing a radio network. The network radio in question has branches in different regions but uses the same station name as its parent. The program contents are identical and are broadcast simultaneously. The extent of broadcast reach point and the diversity of ethnic groups and languages in Indonesia have created the use of television celebrities as radio DJs to span listeners that spread across various islands with limited broadcast areas.

The radio network has a product, a broadcast program that needs the support of radio $D J$ to introduce the program to its listeners. It requires a trustworthy, reliable person to promote program content as radio station products and radio names as brands. It is similar with products (goods) or brands around the world with at least a quarter of the advertisements circulating that use celebrities to promote their products (Shimp \& Andrews, 2013). 
As the leading youth radio in Indonesia, Prambors Radio has produced many radio talents who have become national television celebrities. But on the contrary, when forming a networked radio, Prambors needed famous names of national television celebrities to reach listeners in nine regions in Indonesia. Prambors radio millennial listeners in nine cities have different characters and references to idols or role models. Therefore, in order to facilitate and accelerate the close relationships that are built with its listeners, Prambors chose a role model originating from Jakarta, the capital of Indonesia. Since 1970, Jakarta has become the center of all media in Indonesia, and the Jakarta media plays a key role in media development until now (Hobart, 2006). The use of national television celebrities is considered to be easier to build closeness with the listener, since their appearance, face, and voice are familiar and known by the public through national television.

National television celebrities as radio DJs were employed when Prambors Radio formed a network in the year of 2000. Following this, the use of celebrity radio DJs was not only practiced by Prambors Radio. Other radio networks have since begun to utilize national celebrity as radio DJs. This practice has long been done, but there is a significant gap in the literature on the use of celebrities in radio companies, especially in the radio industry in Indonesia. This research attempts to investigate the research gap, which will be explained in the literature review chapter.

It is commonly acknowledged that celebrities are more widely used to promote of advertiser products, as explained by Chan, Ng and Luk (2013) on a research conducted on Chinese teenagers. They concluded that using celebrities in advertising can increase brand awareness among consumers. Meanwhile, a research on a celebrity for advertiser products in Indonesia has been carried out by Laila and Sjabadhyni (2017), explaining that product purchases using celebrity are higher than the ones without. Amelina and Zhu's (2016) research that focuses on online brands determined that celebrity's credibility can increase attitudes and consumer interest on the product, and this is also what the company owner (Prambors as a brand) aspire to achieve, that the brand awareness of Prambors Radio company is done through the use of Indonesian national celebrities as radio DJs. Based on critical media, this qualitative in-depth research aims to answer the following research question: how are the quality of human resources in Indonesian radio industry and the practice of human resources commodification carried out by Prambors Radio Network? The research objectives are to uncover the quality of radio resources in Indonesia and investigate the practice of commodifying labor on Prambors Radio Network.

The study of radio labor, competition, and organizational changes from a critical perspective makes it possible to discuss, examine, and deepen previous theories on media work. Communication research of media work has shown how celebrity radio DJs have been exploited to push increased work in radio industries. This risk reduces local labor, increases management's power, and controls overproduction. Through observations and interviews, it will be possible to expand our understanding of how celebrity radio DJs and new organizational principles raise marginalized local labor and how the owner's interest shapes power relations in the everyday life of media production.

The research questions will be addressed to the radio owner and practitioner and advertiser to comprehend a successful Prambors Network content by celebrity radio DJs endorsement in reaching listeners that spread across nine regions of Indonesia. To the best of our knowledge, this article is the first to introduce a research on the exploitation of celebrity radio DJs endorsement in developing countries. Consequently, the research findings will contribute to the "industry radio, media management" research stream 
through solving the existing literature gap by observing how effectively celebrity radio DJs endorsement could be used in developing and emerging economies to enhance the numerals of listeners and advertisers. The findings could be used as a ground for future radio management in terms of public and advertiser numerals in other developing and emerging economy with similar cultural setting.

Furthermore, the findings will also suggest practitioners (i.e. radio and advertisers) on how to select effective celebrity endorser to generate public proximity and advertisement and to measure the effectiveness of celebrity endorsement in radio brand and radio advertisement. This should provide an answer on what strategy should the marketers follow to develop successful celebrity advertisement that increases brand awareness for both radios as media and radio advertisement. The rest of this article is arranged as follows: section 2 discusses the existing theories regarding this topic, section 3 discusses the methodology adopted in this research, section 4 presents findings and analysis, and section 5 contains conclusions, limitation, and suggestions for future research.

\section{LITERATURE REVIEW}

Radio host or presenter or radio DJ has the role of mediating information for the audience, encouraging certain activities, and helping the audience to understand information, all of which are centered on what the presenter conveys. Radio is a media, which delivers just audio, accentuated to build the listeners' "theater of the mind". The sight, thought, and gestures they do are all conveyed through the words spoken. It is an acknowledgment that the voice is an instrument of communication (Goffman, 1975). What is said and the person who says it is important in media radio broadcasting. The communicator's credibility is highly necessary to build relationships with the listener. The influence of a communicator will depend on a combination of three components: expertise, trust, and attractiveness. Expertise is the extent to which the communicator is considered a source of valid statements. Trust refers to consumer trust in sources that provide information honestly and objectively. Physically attractive communicators are more successful in changing beliefs (Ohanian, 1990), even though physically radio DJs, are not visible. But with media convergence, the physical features of radio DJs or presenters or radio hosts can also be seen through online media, radio websites, and social media.

Emphasis on sound, articulation, and expression is a determining factor for radio DJs. Authenticity, like sincerity, is a quality that is important for many types of radio DJs or presenters to exhibit. Radio presenters or DJs or hosts form personalities to build close relationships with the listeners (Jamiah, Salasiah, Fazilah, Nurul Nabila \& Mohammad Rezal, 2018). The relationship that builds an intimate relationship between a radio DJ and the listener forms trust so that the listener is willing to share their experiences on on-air interactions. Moreover, since the closeness between the two has been previously established through television because the radio listeners know their faces and voices through television, it is expected that the radio listeners' theater of the mind is awakened when the radio DJ conveys the words.

In recent years, media personality research has increased in media study (Banks, 2007; Bennett, 2010; Bonner, 2011). The media are not only the center of production, circulation, and consumption (Redmond \& Holmes, 2012), but they specifically show interesting celebrities to be analyzed more closely in their way (Bennett \& Holmes, 2010). Television personalities and radio personalities differ from movie stars, who build their 
personalities with their unique media characteristics. Electronic microphones and specific "blindness" medium open up models of personal and intimate relationships when private voices are heard by the public (Nyre, 2008).

Audiences like easy and fun entertainment, indicated by pleasant and sensational experiences through mood mechanisms. In this condition, the audience's relationship with celebrities is based on imaginative activities such as fantasizing and daydreaming (Peter \& Valkenburg, 2006). When audiences embody celebrities as their emotional lines (Holt \& Thompson, 2004), it creates an illusion of intimacy with celebrities (Green, Brock, \& Kaufman, 2004). This makes fantasizing about celebrities a general form of mood management (Knobloch, 2006).

Celebrity endorser, by McCracken's (1989) definition, is anyone who enjoys public recognition and uses that recognition for advertising. Celebrity endorsers appear in various communication modes. For example, celebrity supports business-to-business products and services (Erdogan, 1999), celebrity acts as spokespersons (Michael Jordan of Nike Shoes), and Instagram stories use actor (Brad Pitt) and celebrity as picture of brands (Bergkvist \& Zhou, 2016). The use of celebrity support in advertising is one of the most popular creative strategies (Erdogan, 1999). Most researches conducted have shown that celebrity support is an effective approach in marketing communication and they confirm that celebrity support influences consumer attitudes towards brands (Amos, Holmes \& Strutton 2008). In addition, marketers believe that celebrity gives impact on effective marketing, brand recall, and recognition (Spry, Pappu, \& Cornwell, 2011).

The company brand called "Prambors" was built in 2000 and it now operates in nine regions in Indonesia. The nine radio branches use the same brand, "Prambors", although the broadcast frequency differs in each region. Prambors brand is applied because it has been proven and operating for 48 years. In fact, Prambors is able to evolve a networked station, when the Indonesian radio industry is in decline, marked by RADEX (radio expenditure) of only 0.9\% since 2009 (Nielsen Media Measurement Research, 2018). Aside from that, Prambors is the widest-range youth radio network in Indonesia.

The radio network systems practice in Indonesia is currently carried out through an ownership concentration where the production and marketing of programs are performed by one party, which in this case is the parent radio (Masduki, 2007). Radio network is a corporate strategy for expanding business and audiences (Dominick, 2009) and a form of corporate strategy in terms of resources efficiency. Radio network markets all radio branches together with parent network. Content is produced by parent network and is broadcast via streaming to the branches. Content programs are only produced by parent network for all branches stations (Rivers, Peterson \& Jensen, 2003).

For local radio, the benefits of networked radio are obtaining national advertising, earning national stars, and having a good quality broadcast program (Lane, King \& Russell, 2009). The price of radio network advertising is higher than a single radio, which is determined based on the entire branches number of the audience (De Bonis, 2015). According to Nielsen Radio Measurement, the highest advertisement price is placed at prime time driving time, which are morning show (from 6-10 a.m.), and afternoon show (from 4-8 p.m.). These are the times when national television celebrities are on air as radio DJs to attract listeners and advertisers. National television celebrities are used as homogeneous content program radio DJs because culturally, Indonesians are easily influenced by celebrity endorsement and public figures (Blair, Armstrong \& Murphy, 2003). 
The Indonesian Broadcasting Commission (Komisi Penyiaran Indonesia/KPI) data in 2018 shows that there are currently 15 radio networks operating in Indonesia, all of which are in Jakarta. Jakarta was chosen as parent network because, aside from the fact that it is the nation's capital city, it is also the epicentrum of Indonesia's economy. Advertising agency and the product's principal are located in Jakarta, causing all advertising purchase decisions are made by Jakarta offices. Radio networks are executed through collective marketing programs (Masduki, 2007). In this case, the company makes efficiency by reducing both production and labor costs (Lane, King \& Russell, 2009).

Of the 15 radio networks operating in Indonesia, there are 6 youth segmentation of radio networks, namely: Prambors, I radio, Trax FM, Global FM, OZ radio, and Gen FM. Youth radio (with target age ranging from 15-29 years) can perform if it is well managed, follows technology developments, and meets the listeners' needs (Wan Idros \& Ooi, 2017). Millenials target is considered to have a high level of spending power (Martin \& Turley, 2004). Therefore, a continuing investigation of the millenialis' interests and needs is needed. Although according to Lee, Aisah, Liana \& Siti Suriani (2016), further bondage of listeners on mobile phones radio is not the main thing, listeners still use the radio as a medium to listen to music which can relieve pressure to eliminate boredom (Norshafawati, Asiah \& Fuziah Kartini, 2010). The choice factor of the song being played, the humorous elements, the value of knowledge, and the design of the program are very influential in the selection of radio station.

The study on Indonesian radio network is very limited, especially on radio network that employs television celebrities as radio DJs. Research on Indonesian radio network highlights on the promotion strategy by changing the radio tagline (Maulana, Kuncoro, \& Hikmah, 2013) and media identity selection (Suryadi, 2005). What has not been discussed in the literature is the issue of using television celebrities as radio network workers from the perspective of Vincent Mosco on commodification practice. Mosco, through the political economy of communication, describes it as a study of social relations, underlining the power relations that emphasize the production, distribution, and consumption of resources (Mosco, 2009). Thus, the products or radio broadcasting communication objects are radio programs, with listeners as primary resources. The emphasis of communication objects on radio programs in which radio $\mathrm{DJ}$ is available is considered "solving the problem" on how to maintain and monetize the listener. This capitalist principle is related to the political economy of the media highlighted by Mosco, including the transformation of use-value into a medium of exchange. The workforce is commodified so that it has a sale value, and media owners benefit politically and economically (Mosco, 2009). By using a potential workforce, media content is created to attract two different markets (listeners) and buyers (advertisers) altogether (Albarran, Olmsted, \& Wirth, 2006). In this case, the media functions as a place to meet the needs of the community based on the law of demand and supply (Croteau \& Hoynes, 2001).

\section{METHODOLOGY}

This study uses a qualitative approach with critical media studies through in-depth semistructured interviews with the highest radio executives and central and regional regulators of the Indonesian Broadcasting Commission (Komisi Penyiaran Indonesia/KPI). The selection of research subjects is based on their central position as decision- and policy-makers (Knuth, Kouki \& Strube, 2013), and KPI as an Indonesian broadcasting observer. Hsieh and Shannon 
(2005) state that the research subjects are chosen based on their relevance to the research topic.

To explore the research objectives of Indonesian radio human resources quality and the practice of commodifying labor on Prambors Radio Network, this research has studied Indonesia's largest youth commercial radio company, Prambors Radio Network, and conducted qualitative fieldwork (interviews and observations) in the program department and top management during the period of 2017 to 2018. This research has combined this approach with an analysis of air production, internal production documents, and external texts about the company (e.g online article) at Prambors Radio Network. Through these various materials, this research has assembled an account of how celebrity radio DJs have affected work and production in the company.

Table 1: Research informants

\begin{tabular}{ccl}
\hline No & Name & Details \\
\hline 1 & MS & Founder and CEO of Prambors Radio Network \\
2 & CN & Commissioner of PT. Tomasi Cipta Karya \\
3 & II & President Director of Prambors Radio Network \\
4 & AR & Radio Business Development Consultant of Prambors Radio \\
& Network \\
5 & CP & Content Director of Prambors Radio Network \\
6 & DT & "Morning Show" Radio DJ \\
7 & GN & "Morning Show" Radio DJ \\
8 & IT & "Morning Show" Producer of Prambors Radio Network \\
9 & AS & Commissioner of Indonesian Broadcasting Commission (KPI) \\
& & $2016-2019$ \\
\hline
\end{tabular}

This critical media study is used to uncover realities that are formed by a series of social, political, cultural, and economic factors, which then crystallize into a series of inaccurate structures (Denzin \& Lincoln, 2009). The critical paradigm used in this study is not just to criticize the system but also as a paradigm for changing systems and structures to be more just. Research questions were posed to explore ideas from the informants through 6090 minutes in-depth interviews (Denzin \& Lincoln, 2009), pertaining transformations in the organization of work and labor in music radio production that have come about due to organizational structure change, the implementation of the listeners' need in production, and the push towards company profit orientation. This research tackles questions such as: What effects do these phenomena have on radio organization and radio labor? What does this mean for the creative potentials of local labor music radio work? These questions given to regulators are the extent of supervision over the use of local human resources.

The interview guide was prepared but then shifted to specific questions, depending on the informants' answers, and the discussion was developed based on the informant's point of view. Such an approach helps researchers to be more flexible and adaptable in interviewing informants (Turner, 2010). All interviews were digitally recorded and interview transcripts were analyzed. To test the validity of the data, triangulation techniques were used with interpretive data analysis where data reduction has been carried out since the initial data was obtained. Data presentation was done by displaying data that has been analyzed and are considered to be related to the research problem, including grouping data based on the findings and thematic analyzing (Miles \& Huberman, 1994). 


\section{a. Radio DJs Work and Skills}

\section{RESULT AND DISCUSSION}

Radio DJ plays an important role in managing commercial music radio (Anggrayni, Badrul Redzuan \& Chang, 2018) because of his/her role as the company's spearhead, the face, and corporate ambassador. Another important role of a radio DJ is to capture and maintain listeners by building close relationships so that they are expected to be loyal to the radio station. Radio DJ plays a role in delivering sponsors or advertisers messages aimed at potential consumers who are among the radio listeners. Since radio DJ has an important role, the selection process is therefore not easy. The character of radio DJ must be suitable for the radio target listeners in terms of age, lifestyle, and social class. Another thing that becomes a requirement of radio DJ is general knowledge and music knowledge insight, musical tastes, and speaking style so that listeners can be connected with appropriate characters of radio DJ (Interview with II on March 4, 2018).

Most radio stations in Indonesia recruit radio DJs without broadcasting experiences, but music knowledge and music tastes must be met as its initial requirements. The reason behind this is that they tend to be more easily "polished" in internal training, while experienced radio DJs already have their own "style", making it difficult to change them into the needs of the station according to radio target segmentation. Moreover, the required radio DJs must follow the target listeners, causing the radio segment to largely determine the way the announcer speaks and greets his listeners.

Radio DJs' requirements are quite complicated, especially for radio network. All Indonesian radio networks are located in Jakarta, broadcasting the same contents transmitted to several major cities at the same time. The target market is wide and varied so that the position of a radio DJ is the key to the success of radio network. The company focuses only on morning and afternoon prime time. The listeners listened to the radio more in both prime times as it is driving time, which is believed to capture the highest number of listeners than any other time (Nielsen Media Measurement Research, 2018). For this reason, the radio DJ on air during prime time hours must be special, well-known, and able to build close relationships with the audience.

Choosing a suitable radio DJ for the network audiences segment is a challenge for the company. Although at the beginning it was stated that the radio DJ's character must be in accordance with the intended listener, still, it cannot be used as a definite benchmark, as the position of this radio DJ is more determined by the owner. Although Prambors Radio Network uses online research in determining the character of the radio DJ, the final decision depends on the radio owner (Interview with CP on August 3, 2017).

Prambors Radio Network broadcasts in nine different regions in Indonesia. Through this centralized broadcast model, management selects radio DJs previously known as television celebrities. Television celebrities have been known through audiovisual media. As such, they are expected to quickly build closeness and intimate relationships with listeners. Their familiar faces and voices are utilized by the company to capture a wider listener. Celebrities have the power to reach out listeners spreading across different regions in Indonesia, as their fame is utilized to build an intimate relationship with the listeners (Interview with CP on August 3, 2017).

Radio DJ is highly depended upon to build closeness with loyal listeners. The company expects radio DJ to be able to raise the radio rating and share (number of listeners) (Interview with CN on May 4, 2018). Their role, as influencers or KOL (Key Opinion 
Leaders) in communities becomes the asset which can gain masses (Interview with II on March 4, 2018). As the 250 million people of Indonesian population spreading across the archipelago have differences in language, religion, class, gender, age, and interests (Hobart, 2006), Prambors management hires well-known celebrity to more efficiently tackle with the differences. Primetime radio DJ must be a star or an idol for millennial listeners in the nine regions. This means that radio DJ who greets millennial listeners during prime time hours has a sale value for the markets of Prambors Radio Network, which are listeners and advertisers.

By employing celebrity radio DJ on prime time programs broadcast jointly to all network branches, Prambors Radio has ignored the creativity and the existence of local human resources. Local information is not explored in the content, because it is determined by the parent network and contains more Jakarta-centric information. This is not in line with the existence of radio and broadcast licenses which were issued for the benefit of local communities, not for the people of Indonesia in general (Law 32/2002 on Broadcasting).

One reason why it is difficult to think critically about the media, especially radio, lies in the collusion between the media industry and the political and economic elite. This assumes that broadcast content and reception are determined by the production process and population survey. This is especially important because the capitalists concentrate on increasing the number of audiences which will have an impact in improving the ratings on the AC Nielsen survey and increasing advertisers' buying time.

Vincent Mosco's theory of the political economy of the media addresses the commodification of labor concept, in which commodity process occurs (Mosco, 2009). The use-value becomes the exchange value. This finding was in agreement with Mosco (2009) which states that labor is utilized to provide economic and political benefits for the owner. Celebrity radio DJ uses his/her fame to greet and build the intimacy with the listener on the entire Prambors branches with the aim to increase radio ratings and the number of listeners. The findings of this study also indicate that the radio DJ's background previously known as television celebrity is used as a force to reach a wide-spread listener. In this case, the owner only carries out his interests both economically and politically. Celebrity radio DJ is used by the owner of Prambors to maintain the company's existence. Mezzadri (2016) states that exploitation and commodification cannot be separated; they are two sides of the same coin. In this case, Prambors exploits television celebrity as a radio DJ to reach Prambors Radio's millennial listeners in the nine regions of Indonesia. Media and communication resources have become commodity-products and services sold by companies to buyers or consumers for profit (Wasko, 2014).

\section{b. Celebrity Radio DJs Endorse Wide Audience and Advertiser}

The radio industry employs specialists especially radio DJs or presenters or radio hosts who are not fulfilling their vocational potential, particularly on the aesthetic potential of popular music and broadcast programs. The key organizational units in the radio industry are related to the concept of format, with more emphasis on individual job descriptions on the role. Radio professionals, especially programmers, music director, producer, and program director responsible for the overall sound of a station are motivated to achieve these fifteen-minute "highs". It is indeed a widespread aim of many of those whose vocation is on music radio. The fifteen-minute time must display the creativity of the program team when all factors such as music, presenters, event features, and advertisements come together to 
produce fifteen minutes of audio which perfectly compliments a certain mood or scenario (Interview with MS on November 7, 2017).

The Indonesian radio industry and advertising rely on the results of AC Nielsen's research rating. Advertising agencies in Indonesia use AC Nielsen Media Survey as a reliable measurement tool in choosing the media for promoting their clients' product. The radio broadcasting is competing to make their company in the top 10 radio rankings from the $A C$ Nielsen survey. However, ranks 1-5 are the safest way to get ads. In the rating business, the most important thing is detaining listeners. The listeners, who listen to the radio for eight minutes without switching frequencies, are considered as a fifteen minutes audience or a one-quarter hour audience and are recorded as cumulative audiences (Interview with CN on May 4, 2018). "Cume" illustrate audience size, as they estimate the unduplicated number of people reached by a station at least once during a particular period. Share of the audience is the percentage of total radio listening audience during a given time tuning period to a particular station. Share is a station's average audience expressed as a percentage of the total radio audience for the same period.

The radio industry tends to prioritize the economy, which is reflected in the activities of the employees who are encouraged to treat music and broadcast content as a means to and an opportunity to strengthen the station's brand identity. Prambors Radio, with the largest reach in the millennials Indonesian group market, is exemplary. It is marketed by drawing its brand identity tagline as an "Indonesian number 1 hit music station" that will make the listener "Gaul" (literally means "sociable"). Gaul has been emphasized by the role of Jakarta as a reference point for upward and outward-looking youth in many areas of Indonesia (Ibrihim, 2007; Smith-Hefner, 2007).

Radio broadcasting stations may provide initial work. After work on television decreases or even disappears, the media career continues on film as an actor or dubber. Media work is conducted to maintain public appearances, names, and personalities in public groups nationally (Bonner, 2011). Prambors Radio Network employs two radio DJs previously known as a national television program: Gina, nicknamed "Jeng Kelin" comedian and Desta, a movie actor, drummer, comedian, and currently presenting a national television weekday program entitled "Tonight Show" which has been running for five years. Desta became a Prambors radio DJ in 2002 to 2008. He then continued this role in 2013 until now. Gina, on the other hand, has been a radio DJ since 2011. In 2013, Desta and Gina were conjoined in morning show prime time program (Interview with DT and GN, August 3, 2017).

The name of the prime time morning show program of Prambors Radio Network uses the two television personalities' name: "Desta and Gina in the Morning". The program name works as a basis for their interpretation message to be conveyed and to change the delivery of the message each time it is spoken, which is usually 6-7 times an hour, in the form of "liner". The mention is no longer focused on the name of the station or frequency, but the name of the radio DJs as the program's hosts. It is important to note that Prambors delivers the same content at prime time morning show program in nine different regions in Indonesia, where each region has its frequency number. In this case, the frequency number is ignored, meaning that it is not stated by radio DJs which they usually do. It is instead being replaced by brand names. Prambors Radio Network, broadcasting from Jakarta to its nine radio branch cities, uses the same brand name and station called "Prambors Radio". Apart from the 6-10 a.m. prime time morning show and 4-8 p.m. prime time afternoon 
show, Prambors Radio Network imposes a policy of 4-6 times per hour mentioning the "Prambors Radio, Indonesia's number one hits music station" liner, which is not mentioned on the prime time morning and afternoon show.

The radio liners must comply with the company policy. It has to be "clear, concise and conversational", which means practicing and editing words before opening the microphone fader, without losing the sense of spontaneity. Experienced and confident presenters will be able to "do the sell" from the liner without practice, besides promoting advertiser products or other features or with the target listener in mind, including a Jakarta's reference, news story, joke, or information. Radio DJs are free to create, but there is pressure from top company management to stay within the format rules. Producers, music directors, and program directors who act as program controllers oversee every sound from the radio DJ's microphone. They do not allow them to make mistakes because this can reduce professionalism, which is a key aspect of the station's brand identity. Hence, the tendency for broadcasts to be safe results in a consistent and functional construction. Although radio DJs are allowed more freedom to develop their radio personality, they are still television personalities who are recruited to present radio shows.

The marketing focus of Prambors brand is only in morning shows, using television personality as a radio DJ. Radio brands make people aware of a company's product, in this case morning show program, which becomes an important aspect of the radio station. The number of listeners is needed to ensure the proportion of the sample so that a mass audience is sought. The search for a mass audience means adopting policies, which means encouraging popular music plays and well-known hosts to encourage a large number of listeners. The fact that competitors also adopt this policy and the fact that audiences are not visible mean that the clarity of a company's brand identity is a key factor.

The media profile of radio DJs like Desta and Gina as prime time morning show hosts is a key factor. Since Prambors Radio Network broadcasts in nine regions, large-scale and extensive marketing is required. All branches of Prambors Radio, namely Jakarta, Bandung, Medan, Yogyakarta, Solo, Semarang, Surabaya, Makassar, and Manado are simultaneously marketed by the parent network. Company operational cars, billboards, elevator mall, and other public places are used in Prambors Radio prime time morning show program's promotion. A radio consultant's statement mentions that in the contemporary music radio industry, a strong and successful brand image is built on two factors: the perceived quality and consistency of the sound product available to the audience at all times. These are important to make a strong brand position (Interview with AR on February 15, 2017).

Exploited comedian television personality in media that only displays audio, minimizes the listeners' gap with radio DJs. The advantage of employing television personality is that their identity, face, and voice are well known through television. When their voices are heard in a radio broadcast, the listeners acknowledge and form their "theater of the mind". The audio nature of the radio presents the stage of the mind to each listener so that the words of a radio DJ become a different fantasy for each listener. As such, the radio DJ can make the listener feel comfortable, close, and intimate. This closeness is built through interactive topics related to the radio DJ's personal story to provoke the attention and interaction of live call on air with the listeners (Interview with IT on August 3, 2017). For example, the topic of disappointment is most often done by a partner. Interaction opens with the celebrity radio DJ's comments on topics related to his/her experiences. Listeners are interested in hearing their personal stories that will not necessarily be published through other media. Celebrity radio DJs must open their personal 
lives, making the information or topics delivered a bridge on their personal stories needed by the listeners and are the result of an internal online survey (Interview with CP on August 3, 2017).

Even though the radio DJ lacks music knowledge, particularly international music, the management still considers that they can build close relationships with listeners through "theater of mind" since they have the talent in entertaining audiences on television (Interview with II on March 4, 2018). Since Prambors Radio Network focuses on international music, by playing a percentage of $80 \%$ of international music, the DJs' knowledge on Indonesian music is not highlighted despite the fact that they know more about Indonesian than international music. The international radio consultant who acts as Prambors Radio Network FM business development consultant described that Prambors Radio Network needed to adopt the principles of proven successful radios in the United States and Australia, which entails placing the all-important factor of music firmly within a formatted structure (Interview with AO on February 15, 2017).

Prambors radio DJs are not very knowledgeable in international artist's news. To work their way around this, they only mention the song title and the artist's name that are printed on the computer screen in front of them. However, radio DJs, whose duties are to play music and indulge in an element of aesthetic creativity when it comes to the choice of music, have to be in accordance with the economic industry. Their previous competence to entertain television audiences was utilized to foster close relationships by opening their personal stories to reach wider listeners. The knowledge and experience on international music to cater the needs and interests of Prambors Radio listeners are in this case ignored. Radio DJs employed on prime time morning shows are television celebrities, who are not very knowledgeable in international music. This does not meet the listeners' needs to gain information on international music. In this case, $K P I$ who is responsible for broadcasting supervision is aware of the "Local" regulation. "Local" is defined as local production for the local public using local resources (Interview with AS, March 18, 2018). However, KPI does not impose sanctions on the grounds of limited resources both on broadcast monitoring tools and human resources, making it difficult to prove violations.

Capitalist relationships are determined by their unique shape of labor. In this context, labor is employed as a factor of production, as a workforce. But historically, they are artists or individuals with unlimited creativity and talent (Banks, 2007). As social objects, creative workers are used to the greatest extent possible by capitalists. Creative workers are encouraged to see themselves as autonomous and creative. These creative workers prove to be very tolerant of oppressive working conditions as a result of the efficacy of the company discourse, which is invested only through work, where freedom can be obtained. In relation with this concept, the fame factor of the two radio DJs (Desta and Gina) is used not only through prime-time morning show, but also to connect with social media audiences, through Prambors Radio Instagram account. Their video activities, artist concert news, and radio advertisements are presented by celebrity radio DJs. Their creativity is exploited to the maximum extent to grab audiences not only through program content (on air) but also through off-air and online activities (Singarimbun, Karlinah, Darwis \& Hidayat, 2018).

Littlejohn (2009) describes labor as a form of "expenses" that must be reduced so that the company owner gets more benefit. By exploiting two television celebrities as radio DJs to convey prime time morning show program simultaneously to all Prambors branches, 
the company has closed the opportunity for local human resources to become Prambors Radio DJs in all its branches or local radios. The local potential labor has been marginalized, and at the same time, workers who are at the parent network are exploited with a centralized production system. Radio broadcasting companies must provide benefits and use-value for the local community and not merely become an exchange value for the dominant group because they have also been given a free broadcasting permit by the Indonesian government, which should be returned in a content radio program that is useful for the local community.

Based on the results of this research, the following is the model of labor commodification of radio network:

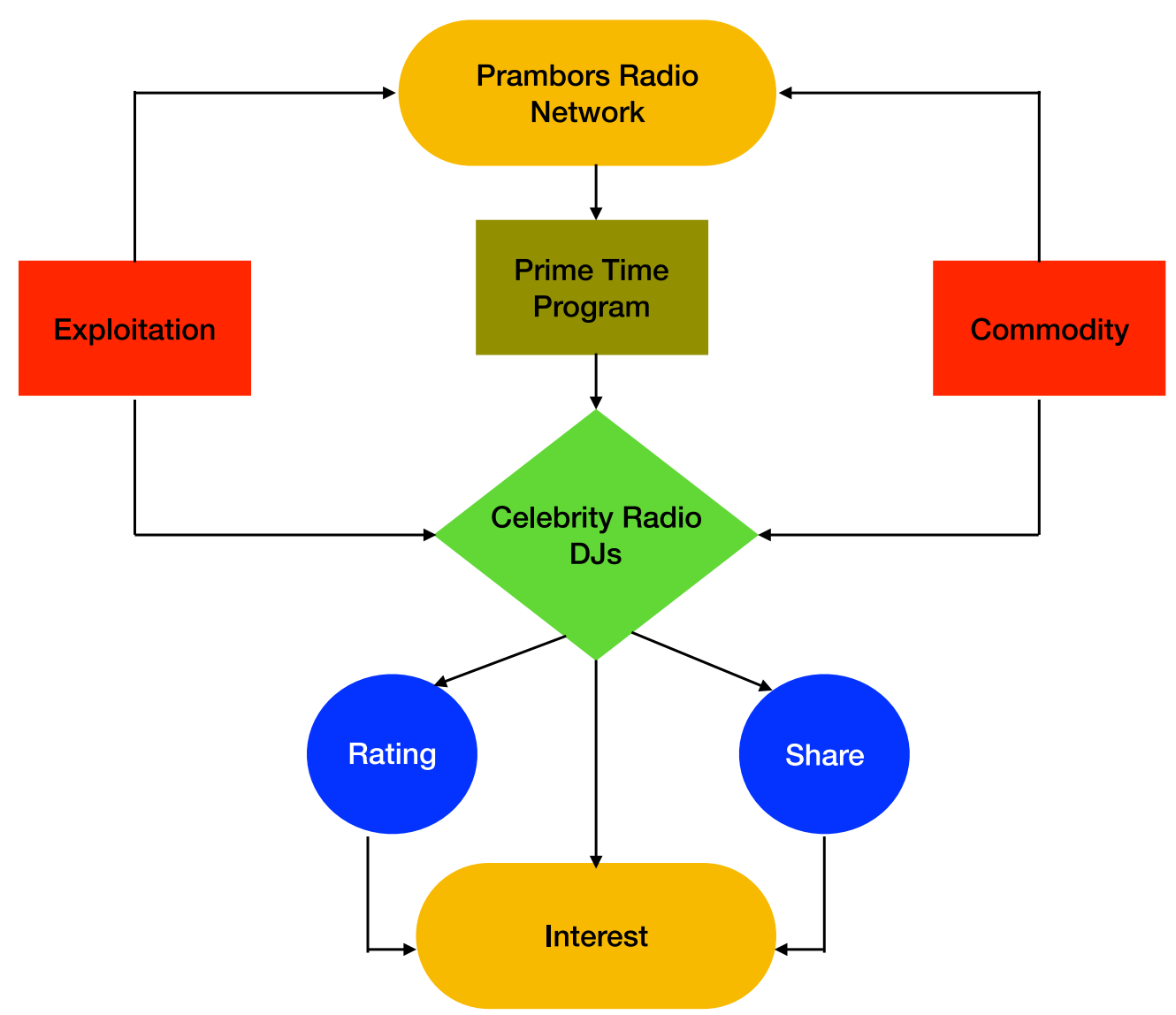

Figure 1: Commodity of celebrity radio DJs

\section{CONCLUSION}

In this article, we have shown how commercial music radio broadcasting uses television celebrities who are known nationally as radio DJs for networked stations. This strategy is to respond to the business competition and it is counted for as company efficiency. This has spurred radio companies (Prambors Radio) to develop new models to captivate and capture audience. Within this reorientation of the established modes of business models, the role of radio DJs has been transformed. In a multiplatform media environment, celebrity Radio DJs' role is increasingly encouraged as an engine to regulate the flow of the audience to create an economic surplus. Celebrity personality systems that have been formed previously through television are radio company strategies to overcome the specificity of the target media market. Celebrity radio DJs are developed as resources that contribute to the 
increase of audience response and to the decrease of production costs. Aside from the identical and simultaneous content of network program, less time is spent on adaptation and innovation. The relationship previously built through national television and it is used to attract the audience's attention based on rapport and their reputation. Credibility, fame, and the radio DJ's personality are tools to keep audiences on the channel. And above all, their presence can motivate them to stay on the program.

Furthermore, in the spot advertising orientation, the existence of celebrity radio $D J$ is increasingly important as a resource for corporate brands and broadcast content to create bonds with audiences that can be used for commercial purposes. Although this certainly creates new problems, when the need for national television celebrity for radio companies is elevated, there will be an increase in wages and benefits.

The strategists and managers of commercial radio companies are emphasizing the importance of new music with high rotation specifically for youth or millennials segmentation. This covers particularly on the importance of celebrity radio DJ's presence that is trusted, well-known, and preferred by the audience to share information and greet them across the nine regions of Indonesia. As such, the credibility of celebrity radio DJ can escalate the audience's share and AC Nielsen radio rating that is connected with airtime purchases by advertising agencies. In the future, Indonesian radio economics may be more focused on radio DJ's personality to grab its audience.

Meanwhile, from the workforce side that is considered specific, unique or irregular, with more emphasis on creative work such as radio DJs, actors, and comedians, Indonesian government creates policies to address the specific conditions of their creative work. Despite the fact that Indonesia already has an Indonesian Creative Economy Institution (Badan Ekonomi Kreatif Indonesia/BERKRAF), which was formed in President Joko Widodo's era (2014-2019) that manages and actively promotes Indonesia's creative industry, until now there are no policies that have been issued regarding creative workforce.

Some limitations of this study need to be recognized. As a new research endeavor, the underlying entertainment mechanisms (e.g., the nature of play, mood management, and boundary loosening between audience and celebrity) need further research. Future research could also further delineate the different levels of engagement for various audience groups. Exploration of these issues and replication of this study in different cultures may help develop a more comprehensive theoretical base for understanding brand endorsement effects, as a central piece of a brand's advertising strategy. 


\section{ACKNOWLEDGEMENT}

This research is a part of a doctoral project on media studies in the Faculty of Communication Sciences, Universitas Padjadjaran, Bandung-Indonesia. The case study is a part of a dissertation titled "Prambors Network Domination towards Local Radio in Indonesia: A Critical Study of Prambors Network". This research did not receive any specific grants from funding agencies in the public, commercial, or non-profit sectors. The researchers would like to express their gratitude to the reviewers.

\section{BIODATA}

Kartika Singarimbun is a PhD candidate at the Faculty of Communication Sciences, Universitas Padjadjaran, Indonesia. Email: kartikasingarimbun@gmail.com

Siti Karlinah is an Associate Professor in Media Studies at the Faculty of Communication Sciences, Universitas Padjadjaran, Indonesia. Email: siti.karlinah@unpad.ac.id

Dadang Rahmat Hidayat is the Dean of the Faculty of Communication Sciences, Universitas Padjadjaran, Indonesia. Email: dadang.rahmat@unpad.ac.id

Yuliandre Darwis is the Chairman of the Indonesian Broadcasting Commission (KPI). Email: yuliandre.darwis@gmail.com 


\section{REFERENCES}

Albarran, A. B., Olmsted, S. M., \& Wirth, M. O. (2006). Handbook of media management and economics. New Jersey: Lawrence Erlbaum Associates.

Amelina, D., \& Zhu, Y. Q. (2016). Investigating effectiveness of source credibility elements on social commerce endorsement: The case of Instagram in Indonesia. PACIS 2016 Proceedings (pp. 232). Retrieved from http://aisel.aisnet.org/pacis2016/232

Amos, C., Holmes, G., \& Strutton, D. (2008). Exploring the relationship between celebrity endorser effects and advertising effectiveness. International Journal of Advertising: The Review of Marketing Communications, 27(2), 209-234.

Banks, M. (2007). The politics of cultural work. NY: Palgrave Macmillan.

Bennett, J. (2010). Television personalities: Stardom and the small screen. London: Routledge.

Bennett, J., \& Holmes, S. (2010). The place of television in celebrity studies. Celebrity Studies, 1, 5-80.

Bergkvist, L., \& Zhou, K. Q. (2016): Celebrity endorsements: A literature review and research agenda. International Journal of Advertising, 35(4), 642-663. doi: 10.1080/02650487.2015.1137537

Blair, M., Amstrong, R., \& Murphy, M. (2003). The 360 degree brand in Asia: Creating more effective marketing communications. Singapore: John Wiley \& Sons.

Bonner, F. (2011). Personality presenters television's intermediaries with viewers. England: Ashgate publishing limited.

Chan, K., Ng, Y., \& Luk, E. (2013). Impact of celebrity endorsement in advertising on brand image among Chinese adolescents. Young Consumers, 14(2), 167-179. doi: 10.1108/17473611311325564

Croteau, D., \& Hoynes, W. (2001). The business of media: Corporate media and the public interest. USA: Pine Forge Press.

De Bonis, S. (2015). A practical guide to the media business. Channai: Cognella Academic Publishing.

Denzin, N. K., \& Lincoln, Y. S. (2009). Handbook of qualitative research (5th ed.). USA: SAGE Publication.

Dewi Anggrayni, Badrul Redzuan Abu Hassan, \& Chang Peng Kee. (2018). Analisis strategi komunikasi ahli parlimen dalam program siaran interaktif di radio Republik Indonesia dan radio Elshinta. Jurnal Komunikasi: Malaysian Journal of Communication, 34(3), 177-191. doi: 10.17576/JKMJC-2018-3403-10

Dominick, J. R. (2009). The dynamic of mass communication (International 5th ed.). New York: Mc-Graw Hill.

Erdogan, B. Z. (1999). Celebrity endorsement: A literature review. Journal of Marketing Management, 15(4), 291-314. Retrieved from http://0www.tandfonline.com.lispac.Isbu.ac. uk/doi/abs/10.1362/026725799784870379

Goffman, E. (1975). The presentation of self in everyday life. Harmondsworth: Penguin.

Green, M. C., Brock, T. C., \& Kaufman, G. F. (2004). Understanding media enjoyment: The role of transportation into narrative worlds. Communication Theory, 14(4), 311-27.

Hobart, M. (2006): Entertaining illusions: How Indonesian elites imagine reality TV affects the masses. Asian Journal of Communication, 16(4), 393-410.

Holt, D. B., \& Thompson, C. J. (2004). Man-of-action heroes: The pursuit of heroic masculinity in everyday consumption. Journal of Consumer Research, 31(2), 425-40. 
Hsieh, H. F., \& Shannon, S. E. (2005). Three approaches to qualitative content analysis. Qualitative Health Research, 15(9), 1277-1288. doi: 10.1177/1049732305276687

Ibrihim, I. (2007). Budaya populer sebagai komunikasi: Dinamika popscape dan mediascape di Indonesia kontemporer. Yogyakarta: Jalasutra.

Jamiah Manap, Salasiah Hanin Hamjah, Fazilah Idris, Nurul Nabila Mohd Izani, \& Mohammad Rezal Hamzah. (2018). Kerelevanan siaran radio terhadap remaja generasi Z di Malaysia. Jurnal Komunikasi: Malaysian Journal of Communication, 35(2). doi: 10.17576/JKMJC-2019-3502-08

Knobloch, S. (2006). Mood management: Theory, evidence, and advancements. In Jennings, B., \& Peter, V. (Eds.), Psychology of entertainment (pp 257-272). Mahwah: Erlbaum.

Knuth, I., Kouki, M., \& Strube, M. (2013). Is it all about the price? Decision drivers affecting ad placement of media planners in magazines. Journal of Media Business Studies, 10(3), 65-85.

Laila, R., \& Sjabadhyni, B. (2017). The influence of celebrity endorsement types and congruency celebrity with the body care products on Instagram users' intention to purchase. Paper presented at Universitas Indonesia International Psychology Symposium for Undergraduate Research (UIPSUR 2017) (pp. 139). doi: 10.2991/uipsur-17.2018.28

Lane, W. R., King, K. W., \& Russell, J. T. (2009). Kleppner's advertising procedure (17th ed.). New Jersey: Pearson Education Inc.

Law 32/2002 on Broadcasting.

Lee Kuok Tiung, Aisah Meri, Liana Mat Nayan, \& Siti Suriani Othman. (2016). Kegunaan dan kepuasan portal berita dalam kalangan belia Malaysia. Jurnal Komunikasi: Malaysian Journal of Communication, 32(2), 790-816.

Littlejohn, S. (2009). Encyclopedia of communication theory (Vol. 1). Los Angeles: SAGE Publications.

Martin, C., \& Turley, L. (2004). Malls and consumption motivation: An exploratory examination of older Generation Y consumers. International Journal of Retail \& Distribution Management, 32(10), 464-475. doi: 10.1108/09590550410558608.

Masduki. (2007). Regulasi penyiaran, dari Otoriter ke Liberal. Yogyakarta: Lembaga Kajian Islam dan Sosial.

Maulana, A., Kuncoro, P., \& Hikmah, L. (2013). 100\% great songs, reverse positioning of Delta FM radio, Indonesia. Emerald Emerging Markets Case Studies, 3(6), 1 - 11.

McCracken, G. (1989). Who is the celebrity endorser? Cultural foundation of the endorsement process. Journal of Consumer Research, 16(December), 310-321.

Mezzadri, A. (2016). Class, gender and the sweatshop: On the nexus between labour commodification and exploitation. Third World Quarterly, 37(10), 1877-1900. doi: 10.1080/01436597.2016.1180239

Miles, M. B., \& Huberman, A. M. (1994). Qualitative data analysis: An expanded sourcebook (2nd ed.). CA: Sage, Thousand Oaks.

Mosco, V. (2009). The political economy of communication (2nd ed.). London: Sage Publication Ltd.

Nielsen Media Measurement Research. (2018).

Norshafawati Saari, Asiah Sarji, \& Fuziah Kartini Hassan Basri. (2010). Muzik dan pembangunan sosial: Paparan dasar industri hiburan dalam akhbar-akhbar di Malaysia. Jurnal Komunikasi: Malaysian Journal of Communication, 26(2), 47-65. 
Nyre, L. (2008). Sound media: From live journalism to music recording. NY: Routledge.

Ohanian, R. (1990). Construction and validation of a scale to measure celebrity endorsers' perceived expertise, trustworthiness, and attractiveness. Journal of Advertising, 19(3), 39-53.

Peter, J., \& Valkenburg, P. M. (2006). Adolescents' Internet use: Testing the 'disappearing digital divide' versus the 'emerging digital differentiation' approach. Poetics, 34(4-5), 293-305.

Redmond, S., \& Holmes S. (2012). Stardom and celebrity: A reader. Thousand Oaks, CA: Sage.

Rivers, W. L., Peterson, J. W., \& Jensen, T. (2003). Media massa \& masyarakat modern (Edisi Kedua, Trans.). Jakarta: Prenada Media Group.

Shimp, T. A. \& Andrews, J. C. (2013), Advertising, Promotion and Supplemental Aspects of Integrated Marketing Communications (9th ed.). Mason, $\mathrm{OH}$ : Thomson SouthWestern

Singarimbun, K., Karlinah, S., Darwis, Y., \& Hidayat, D. R. (2018). Branding is a key to going network: A case study of Prambors network. International Journal of Engineering \& Technology, 7(3.25), 381-385.

Smith-Hefner, N. (2007). Youth language, gaul sociability and the new Indonesian middle class. Journal of Linguistic Anthropology, 17(2), 184-203.

Spry, A., Pappu, R., \& Cornwell, B. T. (2011). Celebrity endorsement, brand credibility and brand equity. European Journal of Marketing, 45(6), 882-909. doi: 10.1108/03090561111119958.

Suryadi. (2005). Media and the margins: Radio in Pekanbaru, Riau (Indonesia). Journal of Southeast Asian Studies, 36(1), 131-51.

Turner, D. W. (2010). Qualitative interview design: A practical guide for novice investigators. The Qualitative Report, 15(3), 754-760. Retrieved from https://nsuworks.nova.edu/tqr/vol15/iss3/19

Wan Idros Wan Sulaiman, \& Ooi Li Woei (2017). Pengkomunikasian pengurusan maklumat dengan budaya kerja di stesen radio Malaysia Kedah FM. Jurnal Komunikasi: Malaysian Journal of Communication, 33(1), 313-339.

Wasko, J. (2014). The study of the political economy of the media in the twenty-first century. International Journal of Media \& Cultural Politics, 10(3). doi: 10.1386/macp.10.3.259_1 